2009

\title{
The Founding Fathers Reconsidered
}

Richard B. Bernstein

New York Law School, richard.bernstein@nyls.edu

Follow this and additional works at: https://digitalcommons.nyls.edu/fac_books

Cart of the Legal History Commons

\section{Recommended Citation}

Bernstein, Richard B., "The Founding Fathers Reconsidered" (2009). Books. 47.

https://digitalcommons.nyls.edu/fac_books/47

This Book is brought to you for free and open access by the Faculty Scholarship at DigitalCommons@NYLS. It has been accepted for inclusion in Books by an authorized administrator of DigitalCommons@NYLS. 
R. B. BERNSTEIN

\section{The Founding Fathers Reconsidered}

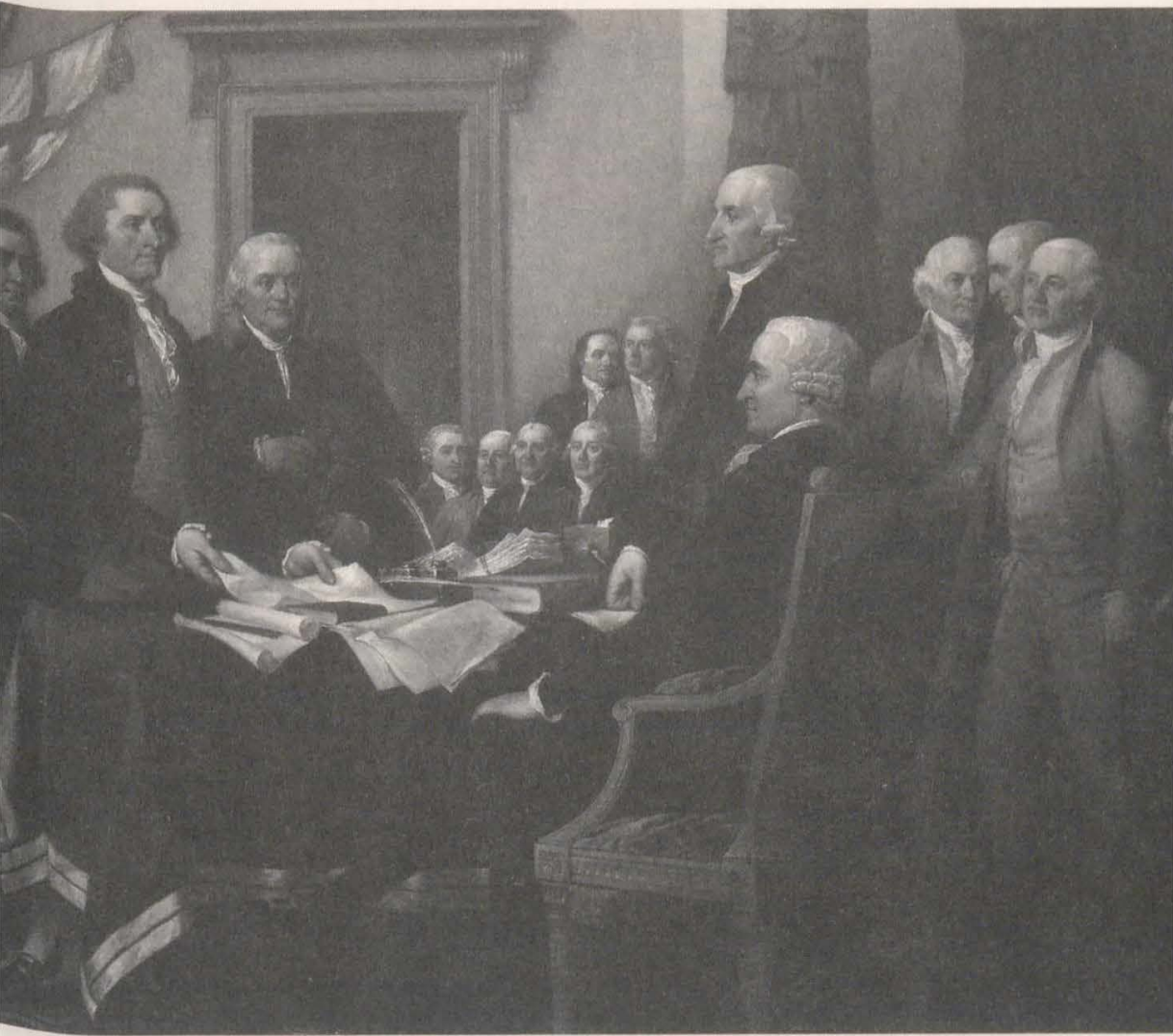

OXFORD

UNIVERSITY PRESS 


\section{OXFORD \\ UNIVERSITY PRESS}

Oxford University Press, Inc., publishes works that further

Oxford University's objective of excellence

in research, scholarship, and education.

Oxford New York

Auckland Cape Town Dar es Salaam Hong Kong Karachi

Kuala Lumpur Madrid Melbourne Mexico City Nairobi

New Delhi Shanghai Taipei Toronto

With offices in

Argentina Austria Brazil Chile Czech Republic France Greece

Guatemala Hungary Italy Japan Poland Portugal Singapore

South Korea Switzerland Thailand Turkey Ukraine Vietnam

\section{Copyright (C) 2009 by R. B. Bernstein}

Published by Oxford University Press, Inc.

I98 Madison Avenue, New York, NY 10016

www.oup.com

Oxford is a registered trademark of Oxford University Press

All rights reserved. No part of this publication may be reproduced,

stored in a retrieval system, or transmitted, in any form or by any means,

electronic, mechanical, photocopying, recording, or otherwise,

without the prior permission of Oxford University Press.

Library of Congress Cataloging-in-Publication Data

Bernstein, Richard B., 1956-

The Founding Fathers reconsidered/R. B. Bernstein.

p. $\mathrm{cm}$. Includes bibliographical references and index.

Summary: "This concise study reintroduces us to the history that shaped the founding fathers, the history that they made, and what history has made of them.

It gives the reader a context within which to explore the world of the founding fathers and their complex and still-controversial achievements and legacies."

- Provided by publisher.

ISBN 978-0-19-533832-4

1. Founding Fathers of the United States.

2. Founding Fathers of the United States-Historiography.

3. United States-Politics and government-1775-1783.

4. United States-Politics and government-1783-1809. I. Title.

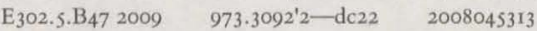

Frontispiece and title page: In John Trumbull's 12 - by 18 -foot painting, now hanging in the U.S. Capitol, John Adams, Roger Sherman, Robert R. Livingston, Thomas Jefferson, and Benjamin Franklin present their draft of the Declaration of Independence to the Second Continental Congress.

Library of Congress LC-USZ62-115965.

987654321

Printed in the United States of America

on acid-free paper 


\section{Contents}

Preface ix

Chronology xiii

Chapter I: Words, Images, Meanings 3

Chapter 2: Contexts: The History That Made the Founding Fathers 12

Chapter 3: Achievements and Challenges: The History the Founding Fathers Made 39

Chapter 4: Legacies: What History Has Made of the Founding Fathers IIS

EpiLogue: The Founding Fathers, History, and Us 168

Appendix: The Founding Fathers: A Partial List 177 Acknowledgments I8I

Notes 187

Further Reading 22I

Index 228 


\section{Preface}

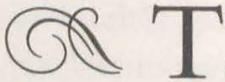

HE FOUNDING FATHERS WERE CREATORS OF the United States and of American national identity, symbols of constitutional democracy, and icons of disinterested statesmanship. They risked all in the service of their great dream of a free, peaceful, and happy nation immune from the corruptions of the Old World and destined to spread across a new, rich continent. They wrote the words and the music to the great American story that posterity has lived by from their time to ours. As we revere them, celebrate their lives, and extol their achievements, we despair of measuring up to them. That is one popular view.

Another view is the photographic negative of the first: The founding fathers were selfish, intolerant, bigoted representatives of a corrupt establishment. They reluctantly gave the great body of the people opportunities to realize their dreams of independence and self-fulfillment, only to smother those dreams by creating a new, powerful general government that suppressed the people and choked their creative energies. Only a peaceful democratic revolution of which Thomas Jefferson was the figurehead and the wordsmith undid the founding fathers' plans. Even then, Jefferson and those whom he led scorned the claims of oppressed groups 
such as enslaved African Americans, Native American peoples, and women. Instead of burning incense before their pedestals, we should knock them down, taking them to task for their sins against democracy.

A third view is much more instrumental. Whether demigods or demons, the founding fathers, creators of the Constitution and the American constitutional system, are the sole determiners of what the Constitution means and how we should apply it to solve pressing constitutional problems. We must pore over the evidence they left behind: the records of their debates both formal and informal, the drafts they prepared and revised and reshaped, the letters they exchanged, the memoranda they wrote for themselves and for the future, and even the diaries that they intended for no eyes other than their own. Only by reference to their words and deeds can we interpret the Constitution responsibly. Otherwise, we would have no restraint on constitutional interpretation, leaving those dreaded and dangerous creatures, free-wheeling judges, free to write into the Constitution whatever ideas or meanings they persuade themselves and us that they can find there.

Readers might object that these three approaches to the founding fathers are caricatures - and they would be both right and wrong. Though exaggerated for dramatic effect, the paragraphs above capture the essence of three prevailing approaches to the founding fathers and their record of achievements and failures.

None of these three approaches to the founding fathers is true. All oversimplify the story of the founding fathers and what that remarkable, fractious group of statesmen, politicians, journalists, farmers, and soldiers did and tried to do. For more than forty years, historians and other scholars have worked to give us a fresh, complex, and nuanced perspective on the founding fathers and their world. Sadly, general readers have little knowledge of this fascinating scholarship, in part because too many scholars write only for one another in gnarled, murky prose and in part because the three caricatures set forth above have achieved such popularity with the 
reading public that they eclipse any other way of looking at the subject.

In this short book, I propose to brush aside those caricatures of the founding fathers and to offer general readers a distilled introduction to the subject, synthesizing the remarkable work that so many of my colleagues have produced. Chapter I explores the words, images, and meanings that we so often associate with the founding fathers and clears the ground for the substantive inquiry the rest of this book presents. Chapter 2 sketches three contextsgeographical, political, and intellectual - that shaped the founding fathers. Chapter 3 explores the array of great challenges that the founding fathers faced, meeting most but not all of them and leaving others for future generations to solve. Taken together, those challenges met and those challenges shirked define the founding fathers' creation of the United States and its constitutional and political systems. Chapter 4 traces the ways that posterity has sought to understand the founding fathers and has come to terms with their labors and ambiguous legacies. The Epilogue uses the words of five great African American orators to explore the concept of perfecting the Union as a way to answer enduring questions about our thorny and conflicted relationship with the founding fathers and their legacies.

I propose to take the founding fathers down from their pedestals without knocking them down. At the same time, I set their achievements and their failures within the context of their own time and place, while making clear that those achievements were not great beyond the bounds of mortal men and that those failures were not blameworthy beyond human beings' normal capacity to err. If we rework our relationship with the founding fathers so that we meet them eye to eye instead of gazing reverently upward or sneering contemptuously downward, perhaps we can form a more pragmatic sense of who they were, what they did and failed to do, and why we care. 


\section{CHAPTER I}

\section{Words, Images, Meanings}

o $\mathrm{N}$ O MATTER HOW MANY HISTORIANS SEEK TO drive a stake through its heart, the phrase "founding fathers" remains a core component of the way Americans talk about politics and government, one with remarkable rhetorical power. Given this fact, we might assume that "founding fathers" has had as long and honorable a history as "All men are created equal." And yet, for an expression so central to Americans' understanding of their past, and so fruitful a source of legal, political, and historiographic controversy, "founding fathers" has a surprisingly short life. It did not enter the political lexicon until the early twentieth century, and its inventor is no one you might expect.

On June 7, I9I6, Senator Warren G. Harding of Ohio delivered the keynote address at that year's Republican National Convention in Chicago. Standing before his enthusiastic audience, Harding seemed the embodiment of a statesman-tall and commanding, his silver hair contrasting dramatically with his dark eyebrows and olive skin. A former newspaper publisher who had won election to the Senate after a failed I9Io campaign for governor of Ohio, Harding was known - and often mocked - for his "bloviation," Ohio political slang for empty, windy oratory. Now he told the cheering crowd of delegates, "We ought to be 
as genuinely American today as when the founding fathers flung their immortal defiance in the face of old world oppressions and dedicated a new republic to liberty and justice."

This I9I6 speech is the first recorded appearance of the phrase "founding fathers"-but Harding had come close four years before, when, at the I9I2 Republican National Convention, also in Chicago, he nominated President William Howard Taft for a second term. Facing a divided and contentious audience (nearly half of whom later bolted from the convention to propel Theodore Roosevelt into a third-party candidacy), Harding was determined to hold the stage for his candidate. Launching his customary long-winded detour through American history, he proclaimed, "Human rights and their defense are as old as civilization; but, more important to us, the founding American fathers wrote the covenant of a people's rule into the bond of national life, beyond all erasure or abridgment." 2 In I9I6, he dropped the intervening "American" and coined a phrase-though at the time nobody noticed.

Over the next five years, Harding periodically revived the phrase "founding fathers." On February 22, I9I8, as the featured speaker at a Washington's Birthday commemoration hosted by the Sons and Daughters of the American Revolution, he declared: "It is good to meet and drink at the fountain of wisdom inherited from the founding fathers of the Republic." Then, in 1920 , after the weary party leaders at the deadlocked Republican convention in Chicago fixed on the Ohio senator as their presidential nominee, Harding twice invoked the "founding fathers" in his acceptance speech. Finally, in his I92I inaugural address, President Harding intoned: "Standing in this presence, mindful of the solemnity of this occasion, feeling the emotions which no one may know until he senses the great weight of responsibility for himself, I must utter my belief in the divine inspiration of the founding fathers. Surely there must have been God's intent in the making of this new-world Republic." 
Harding's creation, with its attendant aura of sanctity, was abroad in the land-passing into general use so swiftly and easily that its origins were soon forgotten. Not until the 1960 , when a television writer posed the question to the Library of Congress's Congressional Research Service, did Harding receive belated credit for creating "founding fathers." Given Harding's weak historical reputation, "founding fathers" may be his most enduring political and intellectual legacy. ${ }^{3}$

The phrase that Harding coined seemed tailor-made to fit a corresponding image (derived from the history paintings of eighteenth-century Europe) that American artists have adapted and revisited with enduring popularity for more than two centuries. From John Trumbull and Amos Doolittle in the early Republic, to Junius Brutus Stearns in the mid-nineteenth century, to Howard Chandler Christy, Henry Hy Hintermeister, and Barry Faulkner in the early twentieth century, to Louis Glantzman during the Constitution's bicentennial, painters and engravers all depicted the nation's founding moments in standard form: a group of carefully dressed, somber politicians, standing or sitting together in a legislative chamber, their attention focused on a document.

Some of these pictures have achieved the status of patriotic icons, in part because of their placement in the temples of the nation's civic religion. For example, John Trumbull's "The Declaration of Independence" and Howard Chandler Christy's "The Signing of the Constitution" hang in the U.S. Capitol, attracting the reverent gaze of thousands of tourists. So, too, Barry Faulkner's murals "The Declaration of Independence" and "The Constitution of the United States" loom above visitors to the National Archives, the building that houses the original parchments of the Declaration and the Constitution. Some of these paintings are genuine works of art, whereas others are lifeless assemblages of familiar faces in a standard matrix. The overall effect is always the same-a staid group of white men, frozen in time. 
This conjunction of words and images raises the question of what Harding's emblematic phrase means. Most scholars identify as founding fathers the politicians, soldiers, jurists, and legislators who held leadership positions during the American Revolution, the Confederation period, and the early Republic. ${ }^{4}$ This category has two subsets, each keyed to one of two founding images. First are the Signers, the delegates to the Second Continental Congress who in July 1776 in Philadelphia's State House (now called Independence Hall) declared American independence and revised and adopted Thomas Jefferson's draft of the Declaration of Independence. Second are the Framers, the delegates to the Federal Convention who met in the same building from May through September of I787 and framed the Constitution of the United States.

At a minimum, the roster would include the seven key leaders named by the historian Richard B. Morris in his 1973 book Seven Who Shaped Our Destiny: Benjamin Franklin, George Washington, John Adams, Thomas Jefferson, John Jay, James Madison, and Alexander Hamilton. (John Jay, however, was neither a Signer nor a Framer; Adams and Jefferson were Signers but not Framers; and Madison and Hamilton were Framers but not Signers. $)^{5}$ These seven men played such central roles throughout the long era of the American Founding that we may plausibly deem them the core of the group known as the founding fathers; for that reason, readers will encounter them regularly in the pages that follow.

Despite these conventional boundaries, "founding fathers" is a protean phrase with varying meanings depending on who has used it and when. Most often, it includes participants on both sides of the $1787-1788$ controversy over ratifying the Constitution. Some have expanded the phrase to embrace not only the usual cadre of elite white males but also Americans of the middling and common sorts who served in the militia or the Continental Army or Navy during the American Revolution, who voted for delegates to the state conventions that were to ratify the Constitution, and who helped to bring the new government into existence. ${ }^{6}$ 
Some historians substitute the phrase "revolutionary generation"though this group actually spanned three or even four generations, from Benjamin Franklin to Albert Gallatin.

Some political writers highlighting the role of women in American history confer the honorific term "founding mothers" on women such as Abigail Adams, Mercy Otis Warren, and Deborah Sampson. ${ }^{7}$ Other biographers affix the term to historical figures falling outside its chronological boundaries - from John Winthrop, the first governor of the Massachusetts Bay Colony, to the late Senator Samuel J. Ervin, Jr. (D-NC), who won fame as chairman of the Senate's Watergate Committee in $1973-1974$, to Brian Lamb, founder of C-SPAN. ${ }^{8}$ Finally, biographers studying major historical figures falling within the category of founding fathers stress the point by labeling their subject as a "forgotten founder," a "forgotten founding father," or, in the case of Aaron Burr, a "fallen founder.", Significantly, however, the phrase usually has excluded those who were not white, whether African American or Native Americanthough a controversial 1987 monograph labels Native Americans as "forgotten founders" and a 2008 biography of the African American clergyman Richard Allen dubs him a "founding father."

Whatever the group's extended membership, the core meaning of "founding fathers" remains constant. It designates those who, by word or deed, helped to found the United States as a nation and a political experiment. Thus, beyond the "seven who shaped our destiny" named by Richard B. Morris, the term includes those who sat in the Congress that declared American independence; it even includes a delegate such as John Dickinson of Pennsylvania, who opposed independence and refused to sign the Declaration but fought for the American cause in the Revolutionary War, and a polemicist such as Thomas Paine, who only briefly held political office but was an extraordinarily effective educator and mobilizer of public opinion. It also encompasses others who fought on the American side in the war, or played important roles (as framers, ratifiers, opponents, or effectuators) 
in the origins of the Constitution of the United States and the system of government it outlines.

In studying the founding fathers, we study a political elite, though a more porous and open elite than those holding sway in Europe. ${ }^{11}$ In addition, that elite increasingly had to interact with the people during the Revolution and in the eras of the Confederation and the early Republic. Though they may have sought to direct the course of events, at least as often they had to respond to changes coming from below and to shifts of opinion among the people, who increasingly were inclined to express their own views, follow their own lead, and challenge the primacy of their ostensible governors. One of the most rewarding and disturbing subthemes of current scholarship is the profusion of carefully researched studies again casting doubt on the disinterestedness of the founding fathers, highlighting clashes of ideals and interests between different levels of American society, causing at least some among the "ordinary people" to wonder whether the American victory in the Revolution was a hollow triumph. For these reasons, reconsidering the founding fathers within their historical context illuminates the evolution of American politics and democracy, complementing the work of those who concentrate their attention on the great body of the people or on those other groups previously excluded from historical study. ${ }^{12}$

Yet another point to keep in mind when reconsidering the founding fathers is that they sought to order the world, not primarily by force but with words, by framing and adopting a series of documents of political foundation: constitutions, declarations or bills of rights, treaties, and laws. John Adams rightly called his time "the age of revolutions and constitutions." 13 The possibilities and limitations of ordering the world with words is a theme running through their writings - giving them hope and causing them frustration, often at the same time. In this light, reexamining the founding fathers helps us to recover a broader sense of the possibilities and purposes of political thought and action. 
Finally, reconsidering the founding fathers makes it necessary to explore the complex story of their historical reputations, both as members of that fabled group and as individuals, as well as their legacies in the two centuries since the Revolution. As the political scientist Seymour Martin Lipset argued, the United States is "the first new nation" - the first nation to be created at a specific time and place, in a specific act of political invention, having at its core not shared ethnicity or language or religion but rather shared commitment to a set of defining principles as a national "political creed" or "civil religion." 14 Inevitably, this defining quality of American national identity and American nationalism focuses attention on the founding fathers and their handiwork. ${ }^{15}$ Among other things, American history is an ongoing story of how successive generations have wrestled with the clashing imperatives of preserving the founding fathers' legacies and reforming or transforming them in the face of changing values, problems, and circumstances. We argue over ideas such as liberty, equality, national identity, separation of church and state, the purposes of constitutional government, and the proper workings of that government in terms invented or shaped by the founding fathers. Just as often, we either invoke them as oracles guiding modern constitutional government or reject them as irrelevant to very different modern issues. To put it another way, we continue the process that they began of struggling to order the world with words, sometimes quarreling over how best to interpret the words they used and sometimes seeking to revise or add to the words and texts they left us.

The founding fathers still draw the attention not only of scholars but of Americans in all walks of life; their words are still accessible to us, and the challenge of understanding what they meant or should have meant is irresistible and urgent. Major constitutional crises, spawning disputes over whether and how "original intent" can resolve them, intersect with public uncertainty about the lessons that the "usable past" can or should teach. ${ }^{16}$ On the one hand, we celebrate the founding fathers for erecting a 
standard of wise statesmanship for posterity to emulate and leaving a precious legacy for posterity to preserve. On the other hand, we argue bitterly over whether and why the founding fathers failed to confront the central moral and constitutional issue of their era: chattel slavery and its attendant implications for issues of race and equality.

The recent sense of crisis that has enveloped the American people has brought with it a resurgent reverence for the founding fathers. To be sure, this is nothing new in American history. In I94I, with the United States poised on the brink of World War II, the novelist and critic John Dos Passos wrote in his book analyzing the American political creed, The Ground We Stand On: "In times of change and danger, when there is a quicksand of fear under men's reasoning, a sense of continuity with generations gone before can stretch like a lifeline across the scary present and get us past the idiot delusion of the exceptional." ${ }^{17}$ Dos Passos's words apply equally well, six decades later, to the American state of mind in the wake of Bush v. Gore (2000) and the terrorist attacks on New York City and Washington, D.C., on September II, 200I. ${ }^{18}$ In this troubled era, many question the ability of the constitutional system to respond to grave national problems. At the same time, looking back to history for reassurance, many Americans found in John Adams a Churchillian figure of reassuring toughness, in Alexander Hamilton a forthright, realistic champion of national interests, and in Thomas Jefferson an eloquent spokesman for values and principles under attack in a hostile world. Notwithstanding sharp differences between scholarly and popular understandings of the Revolution and the Constitution, once again the appeal of a mythologized cadre of founding fathers has become nearly overwhelming.

The influence of the founding fathers extends beyond the borders of the United States. Beginning in the mid-I980s and continuing in the twenty-first century, people around the world have tried to replace corrupt, oppressive governments with 
constitutional democracies, and in the process have sought guidance from the American founding. This is only the latest chapter of a story reaching back to the era of the founding fathersbeginning with the efforts of liberal French politicians and philosophes such as the Marquis de Lafayette and the Marquis de Condorcet to frame the French Declaration of the Rights of Man by reference to American exemplars (with a discreet assist from the American minister to France, Thomas Jefferson). The trend continued - in the early nineteenth century, when new republics broke free of Spain's disintegrating Latin American empire; in the decades following the Second World War, when European nations dismantled their colonial empires and emerging nations in Asia and Africa experimented with the blessings of constitutional selfgovernment; and in the decades since 1989, when former members of the Warsaw Pact and other former tyrannies rejected dictatorship in favor of constitutional democracy.

Even though most nations have adopted a form of government-parliamentary democracy-significantly different from the presidential system outlined in the U.S. Constitution, they still have adopted the idea of a democratic government with a written constitution and declaration of rights at its core. The example of "political building" they follow is American, even if the constitutional and political architecture they build is their own. ${ }^{19}$ The experiment launched by the founding fathers retains significance for a wider world. We now must turn to the ways that the wider world shaped the founding fathers, more than two centuries ago. 